\title{
Livelihood pattern of rural women garment workers at Dhaka city
}

\author{
R.N. Ali, F. Begum, M.M. Salehin and K.S. Farid \\ Department of Rural Sociology, Bangladesh Agricultural University, Mymensingh-2202.
}

\begin{abstract}
The study was an attempt to analyse the economic, social and health conditions of women garment workers as well as their livelihood pattern. Three garment factories from Mirpur area under Dhaka district were selected purposively. The sample consisted of 90 women workers taking 30 randomly from each of the three garment factories. Data were collected through personal interviews with the selected samples. It was found that most of the respondents migrated to Dhaka because of their extreme poverty or insolvency. Few respondents had brought positive changes in their financial capital, decision marking and empowerment etc. The study revealed that 63.33 percent respondent's livelihood pattern has improved after involving in garment factory. Some diseases like eye trouble, headache, ear ache etc to be more prevalent among the women garment workers due to their involvement in garment factories. Incidence of physical weakness among the garment workers was very high. Women are exploited easily due to lack of technical knowledge and training. The employers do not pay any heed to this exploitation.
\end{abstract}

Key words: Rural women, Urban garments, Livelihood, Garment workers

\section{Introduction}

Readymade Garment (RMG) is the leading sector of Bangladesh in terms of employment, production and foreign exchange earning (World Bank, 1990). This sector earned about 76 percent of the yearly foreign exchange earning of the country (BGMEA, 2008). The importance of RMG sector can hardly be over emphasized. This sector has uplifted the neglected section of the population, i.e. women, thus radically transforming the socioeconomic condition of the country through empowerment and employment generation. Such empowerment and employment raised awareness regarding child education, health safety, population control, disaster management, so on and so forth (Sobhan and Khundker, 2001). Out of 2.4 million manpower employed in RMG sector, 2.04 million are women (BGMEA, 2008). This is mainly because the garment industry is quite susceptible to fluctuations in employment as a result of seasonal variations and fashion changes. These characteristics demand a labour market with high flexibility, a market in which labour is easily found when it is needed and is easily disposed off when not wanted. The availability of a large number of unskilled or semi-skilled women workers for employment, however, has been an important contributing factor in the growth of the garment industry in Bangladesh.

Very little is known about the socioeconomic conditions of the garment workers because specific study on livelihood pattern of women workers was very limited. Various studies were undertaken in various times by different researchers throughout the world regarding the economic, social and health conditions of garment workers. Kabeer (2000) in his study examined that the majority of women workers rated their access to employment in the garment factories in positive terms because of its improvement on what life had been like before. Paul-Majumder (2003) conducted a study on the physical and mental health status of garment workers and how problem affect labour productivity, competitiveness of the garment industry in the world market and the working life of the workers, particularly of female workers. A large number of workers were found to continue their work even they were suffering from various diseases and illness. Most of the health problems that the garment workers suffered from arose from the occupational hazards including long working hours, absence of leave facilities, congested and over crowded working conditions etc. Halim and Kabir (2005) found that the positive and negative impacts of globalization on women within the prevailing unequal gender division of labour gave special emphasis on the situation of 
female labour force in the RMG sector. Women constitute a lions share of the total labour force in the RMG sector, which bring most of the country's foreign currency. But women were exploited easily due to lack of technical knowledge and training. So, keeping the above view in mind the present study was undertaken to analyse the changing livelihood pattern of urban women garment workers who move from rural areas to urban garments. The specific objectives of the study were i) to know about the present socio-economic status of women working in garment sector; ii) to explore reasons of women's involvement in garment sector; iii) to identify major changes in livelihood took place after involvement in garments; and iv) to explore the empowerment issues of women garment workers.

\section{Materials and Methods}

Mirpur upazila under Dhaka district was selected purposively, where garment factories are available. Three factories were selected purposively considering the purpose of the researchers. A sample of 90 respondents, taking 30 from each factory was chosen randomly. Primary data were collected personally from the respondents through a sample survey with the help of a structured and pre-tested interview schedule. In this study, quantitative method like a survey method was chosen in order to get a reasonably true picture of the entire population. The data were collected during the period from February to April, 2008. Tabular method was used for a substantial part of data analysis. Relatively simple statistical techniques such as percentage and arithmetic mean or average were taken into account to analyse the data and to describe socioeconomic characteristics of the respondents, type of work, length of services, etc.

\section{Results and Discussion}

\section{Causes of migration}

Several factors seemed to be responsible for the migration of rural women for employment in urban garments. The majority (58.9 percent) of the women were migrated for extreme poverty or insolvency. Thus the first reason for migration from rural areas to Dhaka was extreme poverty. The second important factor was search of job. About 19 percent of the respondents were migrated for this reason. The third and fourth important causes identified by the migrants were husband work in Dhaka and educational purposes, respectively (Table 1).

Table 1. Reasons for migration

\begin{tabular}{|l|c|c|}
\hline \multicolumn{1}{|c|}{ Reasons } & No. of respondents & Percent \\
\hline Extreme poverty /Insolvency & 53 & 58.9 \\
\hline Search of job & 17 & 18.9 \\
\hline Marriage/Husband work in Dhaka & 12 & 13.3 \\
\hline Educational purposes & 5 & 5.6 \\
\hline Others & 3 & 3.3 \\
\hline Total & 90 & 100 \\
\hline
\end{tabular}

Source: Field survey (2008)

\section{Reasons of involving in RMG}

Of the total female workers, 71.1 percent women entered into the garment factories to help their family financially. A proportion of 52.2 percent and 51.1 percent entered into the garment factories to satisfy their basic needs and to uplift their living standard, respectively. The respondents also entered into RMG factory for other reasons such as to become independent, to get facilities in marriage, etc (Table 2). 
Table 2. Reasons of involvement in readymade garment (RMG)

\begin{tabular}{|l|c|c|}
\hline \multicolumn{1}{|c|}{ Reasons } & $\begin{array}{c}\text { No. of respondents } \\
(\mathrm{n}=90)\end{array}$ & Percent \\
\hline To secure more income & 9 & 10.0 \\
\hline To help family financially & 64 & 71.1 \\
\hline To uplift living standard & 46 & 51.1 \\
\hline To become independent & 31 & 34.4 \\
\hline To get facility in marriage & 5 & 5.6 \\
\hline To get facilities of health care & - & - \\
\hline To satisfy basic needs & 47 & 52.2 \\
\hline Others & 3 & 3.3 \\
\hline
\end{tabular}

Source: Field survey (2008)

Note: Percentage may not sum to 100 percent because of multiple responses

\section{Work pattern of women in garment factories}

Table 3 shows that about 28 percent of the women workers were polyer, while 24.4 percent were finishing helpers. There was no women worker as cutting master, iron helper and support staffs because the women workers lacked basic training for such kind of positions. Operators and sewing helpers were 23.2 and 12.2 percent, respectively.

Table 3. Distribution of women workers according to their type of work performance

\begin{tabular}{|l|c|c|}
\hline Work pattern & No. of respondents & Percent \\
\hline Quality controller & 3 & 3.3 \\
\hline Cutting master & - & - \\
\hline Supervisor & 2 & 2.2 \\
\hline Cutting helper & - & - \\
\hline Operator & 21 & 23.2 \\
\hline Sewing helper & 11 & 12.2 \\
\hline Iron helper & - & - \\
\hline Folding & 3 & 3.3 \\
\hline Finishing helper & 22 & 24.4 \\
\hline Polyer & 24 & 27.8 \\
\hline Embroidery & 1 & 1.1 \\
\hline Line chief & 3 & 3.3 \\
\hline Support staffs & - & - \\
\hline Total & 90 & 100 \\
\hline
\end{tabular}

Source: Field survey (2008)

\section{Monthly income by length of service}

A proportion of 8.89 percent of the women had 1 year service length. On the other hand, 65.55 percent, 23.33 percent and 2.22 percent women had 2 years, 3 years and 4 years service length, respectively. About 20 percent respondents whose job length was 2 years, earned Tk. 2301-2700 and 13.33 percent earned Tk. 1900-2300. On the other hand, 21 female workers worked for 3 years, of them 11.11 percent earned salary Tk. 2701-3000 (Table 4). 
Table 4. Distribution of women garment workers according to their length of service and monthly income

\begin{tabular}{|l|c|c|c|c|c|}
\hline \multirow{2}{*}{$\begin{array}{c}\text { Monthly income } \\
(\text { Tk.) }\end{array}$} & \multicolumn{3}{|c|}{ Length of service (in years) } & \multirow{2}{*}{ Total } \\
\cline { 2 - 5 } & $1(\%)$ & $2(\%)$ & $3(\%)$ & $4(\%)$ & \\
\hline$<1900$ & $1(1.11)$ & $19(21.11)$ & - & - & 20 \\
\hline $1900-2300$ & $6(6.67)$ & $12(13.33)$ & $4(4.44)$ & - & 22 \\
\hline $2301-2700$ & - & $18(20.00)$ & $7(7.78)$ & $1(1.11)$ & 26 \\
\hline $2701-3000$ & $1(1.11)$ & $10(11.11)$ & $10(11.11)$ & $1(1.11)$ & 22 \\
\hline Total & $8(8.89)$ & $59(65.55)$ & $21(23.33)$ & $2(2.22)$ & 90 \\
\hline
\end{tabular}

Source: Field Survey (2008)

\section{Monthly income by education category}

Of the total female workers, only 1.1 percent female workers earned Tk. 1900 per month and they were illiterate. About 16 percent whose educational level was secondary, earned Tk. 1900-2300. The female workers whose earned Tk. 2301-2700 were about 26 percent and had secondary education (Table 5).

Table 5. Distribution of women garment workers according to their education and Monthly income

\begin{tabular}{|l|c|c|c|c|c|}
\hline \multirow{2}{*}{$\begin{array}{c}\text { Monthly income } \\
\text { (in Taka) }\end{array}$} & \multicolumn{4}{|c|}{ Education } & \multirow{2}{*}{ Total } \\
\cline { 2 - 5 } & Illiterate & Primary & Secondary & $\begin{array}{c}\text { Higher } \\
\text { secondary }\end{array}$ & \\
\hline$<1900$ & $1(1.11)$ & $10(11.11)$ & $9(10.00)$ & - & 20 \\
\hline $1900-2300$ & - & $8(8.89)$ & $14(15.56)$ & - & 22 \\
\hline $2301-2700$ & - & $3(3.33)$ & $23(25.56)$ & - & 26 \\
\hline $2701-3000$ & - & $7(7.78)$ & $14(15.56)$ & $1(1.11)$ & 22 \\
\hline Total & $1(1.11)$ & $28(31.11)$ & $60(66.68)$ & $1(1.11)$ & $90(100)$ \\
\hline
\end{tabular}

Source: Field Survey (2008)

\section{Payment schedule by age category}

Table 6 shows that about 72 percent female workers got their salary in the $1^{\text {st }}$ week of the month where about 7 percent of them got salary in the $2^{\text {nd }}$ week, and 21.11 percent in the third week of the month. About 36 percent female workers of aged between 20 and 25 years got salary in the first week of the month. It could be because this aged workers are competent, skilled and productive and if not given salary in time, the employer might encounter resistance from them. No women worker was found to get their salary in the $4^{\text {th }}$ week of the month.

Table 6. Distribution of women garment workers according to their age category and payment schedule

\begin{tabular}{|l|c|c|c|c|c|}
\hline \multirow{2}{*}{$\begin{array}{c}\text { Age category } \\
\text { (years) }\end{array}$} & \multicolumn{4}{|c|}{ Payment schedule (week) } & \multirow{2}{*}{ Total } \\
\cline { 2 - 5 } & $1^{\text {st }}$ & $2^{\text {nd }}$ & $3^{\text {rd }}$ & $4^{\text {th }}$ & \\
\hline $15-20$ & $26(28.89)$ & $2(2.22)$ & $19(21.11)$ & - & 47 \\
\hline $20-25$ & $32(35.56)$ & $1(1.11)$ & - & - & 33 \\
\hline $25-30$ & $7(7.78)$ & $3(3.33)$ & - & - & 10 \\
\hline Total & $65(72.23)$ & $6(6.66)$ & $19(21.11)$ & - & $90(100)$ \\
\hline
\end{tabular}

Source: Field survey (2008) 


\section{Work hour and overtime rate}

There was one shift of work to be the norm in the garment industry. As in any other industry, the normal working hours in the garment factory is 9 hours a day, usually from 8 a.m. to 5 p.m. There is a seasonality in its production, hence work hours vary accordingly. The peak season is from October to January, while the slack season is from March to June. As the labour requirement increases during the peak season, the workers are required to work overtime.

According to the Factory Act 1965, no person can be employed for more than 8 hours a day in a factory. Work in excess of these hours should be paid for at the overtime rates, which is twice the basic salary. Usually, the basic salary is considered to be 60 percent of the monthly pay. Thus a worker should get 1.2 times his/her hourly pay for one hour of overtime. The basic salary of the garment workers is expected to be $45-47$ percent of the total salary. But none of the female workers knew about their basic salary. Most of the respondents were ignorant about how the rate is calculated. Table 7 shows that 74.44 percent respondents got Tk. 6-10/hour overtime. About 19 percent respondents got Tk. 11-15/hour overtime.

Table 7. Overtime rate

\begin{tabular}{|l|c|c|}
\hline Wage (Tk./hour) & Number & Percent \\
\hline $6-10$ & 67 & 74.44 \\
\hline $11-15$ & 17 & 18.89 \\
\hline $16-20$ & 6 & 6.67 \\
\hline Total & 90 & 100 \\
\hline
\end{tabular}

Source: Field survey (2008)

\section{Changing financial capital}

Financial capital includes financial resources such as saving, income, bond, debenture, etc. Here information about saving and income as major financial resources of the women garment workers were collected. Table 8 indicates percentage of women garment workers response to change their saving and income.

It reveals that only 12.2 percent of the respondents' households saving has increased after involving in garment factory while 38.9 percent was opined that no change in their household saving has taken place. The savings of about half (48.9 percent) of the women workers decreased as a result of their involvement in RMG. In case of income, 67.8 percent of the respondents felt that their household income has increased due to increased in income after involving in RMG while 27.8 percent respondents mentioned that no change in income took place.

Table 8. Distribution of women garment workers according to their degree of change in the financial resources

\begin{tabular}{|l|c|c|c|}
\hline \multirow{2}{*}{ Types } & \multicolumn{3}{|c|}{ Degree of change } \\
\cline { 2 - 4 } & Increased & Unchanged & Decreased \\
\hline Saving & $11(12.2)$ & $35(38.9)$ & $44(48.9)$ \\
\hline Income & $61(67.8)$ & $25(27.8)$ & $4(4.4)$ \\
\hline
\end{tabular}

Source: Field survey (2008) 


\section{Decision making and empowerment}

In Bangladesh, women are still lagging behind in case of decision making and empowerment of the households. This situation is improving gradually through the involvement of women in different activities. Involvement in garment factory is one of them. Though most of the female workers are dominated by male person of the household, women involvement in buying and selling, food selection, children education etc., are crucial for their improvement. Table 9 shows that 45.6 percent female workers decision making ability in case of buying and selling has increased after involving RMG factory while 71.1 percent in case of food selection, 54.4 percent in case of children education, 68.9 percent in case of treatment has improved.

Table 9. Decision making and empowerment issues

\begin{tabular}{|l|c|c|c|}
\hline \multirow{2}{*}{\multicolumn{1}{c|}{ Aspects }} & \multicolumn{3}{c|}{ Degree of change } \\
\cline { 2 - 4 } & Increased & Unchanged & Decreased \\
\hline Buying and selling & $41(45.6)$ & $36(40.0)$ & $13(14.4)$ \\
\hline Food selection & $64(71.1)$ & $22(24.4)$ & $4(4.4)$ \\
\hline Children education & $49(54.4)$ & $36(40.0)$ & $5(5.6)$ \\
\hline Treatment & $62(68.9)$ & $16(17.8)$ & $12(13.3)$ \\
\hline Deposit & $11(12.2)$ & $35(38.9)$ & $44(48.9)$ \\
\hline Nursing & $61(67.8)$ & $25(27.8)$ & $4(4.4)$ \\
\hline Family planning & $42(46.7)$ & $36(40.0)$ & $12(13.3)$ \\
\hline Choice of work & $61(67.8)$ & $28(31.1)$ & $1(1.1)$ \\
\hline Visit to relatives & $41(45.6)$ & $17(18.9)$ & $32(35.6)$ \\
\hline Social and religious function & $42(46.7)$ & $18(20.0)$ & $30(33.3)$ \\
\hline
\end{tabular}

Source: Field survey (2008)

\section{Types of diseases and illnesses}

Work in the garment factory severely affects women's health, as they are confined in a closed environment. The particular nature of work in the RMG factory creates various types of health hazards especially for women. Results of the study showed (Table 10) that the most frequent illness reported by 70 percent of the female workers was headache. Gastritis was more prevalent among the female workers. About 47 percent suffered from gastritis problem. The third common complaint was musculoskeletal pain. In general, 36.7 percent workers suffered from some kind of weakness. This occurred due to long hours of work and low quality of food that they took for lunch. About 33.3 and 21.1 percent women workers reported that they were having ear ache and eye pain, respectively after joining the garment.

\section{Table 10. Type of diseases and illnesses}

\begin{tabular}{|l|c|c|}
\hline Diseases and illnesses & No. of respondents $(\mathrm{n}=90)$ & Percentage \\
\hline Headache & 63 & 70.0 \\
\hline Musculoskeletal pain & 34 & 37.8 \\
\hline Ear ache & 30 & 33.3 \\
\hline Physical weakness & 33 & 36.7 \\
\hline Eye pain & 19 & 21.1 \\
\hline Less appetite & 15 & 16.7 \\
\hline Chest pain & 29 & 32.2 \\
\hline Fainting & 24 & 26.7 \\
\hline Diarrhoea & 25 & 27.8 \\
\hline Jaundice & 14 & 15.6 \\
\hline Skin disease & 29 & 32.2 \\
\hline Gastritis & 42 & 46.7 \\
\hline Typhoid & 14 & 15.6 \\
\hline Others & 26 & 28.9 \\
\hline
\end{tabular}

Source: Field survey (2008) 


\section{Problems faced by women workers outside and inside the garment factory}

It is often said that a lot of mishappenings occur within and outside the garment factories. The incidences can take place at the factory, on the street, or at the residence of the workers. Of the total 90 female workers, 98.9 percent reported that transport was the main problem for female workers, which was followed by housing problem (87.8 percent). Many incidents such as attack by hijacker, local mastans and harassment by police in the streets were reported by the workers. On the other hand, 68.9 percent of the total female workers were beaten inside the factory and sometimes they were also beaten by their colleagues. About 60 percent female workers reported that they suffered from the fear of dismissal. Operators were relatively more afraid of being dismissed. The incidence of rape in the factory was reported by 27.8 percent female workers (Table 11 ).

Table 11. Problems faced by women workers outside and inside the garment factory

\begin{tabular}{|l|c|c|l|c|c|}
\hline \multicolumn{1}{|c|}{ Outside the factory } & \multicolumn{3}{c|}{ Inside the factory } \\
\hline Types & $\begin{array}{c}\text { No. of } \\
\text { respondents } \\
(\mathrm{n}=90)\end{array}$ & Percent & \multicolumn{1}{c|}{ Types } & $\begin{array}{c}\text { No. of } \\
\text { respondents }\end{array}$ & Percent \\
\hline $\begin{array}{l}\text { Communication } \\
\text { problem }\end{array}$ & 89 & 98.9 & Beating in the factory & 62 & 68.9 \\
\hline Housing problem & 79 & 87.8 & Lack of place for taking food & 28 & 31.1 \\
\hline Attack by hijacker/touts & 68 & 75.6 & Sexual harassment & 2 & 2.2 \\
\hline Afraid of local mastans & 67 & 74.4 & Raped by male colleague & 25 & 27.8 \\
\hline Harassed by police & 6 & 6.7 & Fear of dismissal & 54 & 60.0 \\
\hline Others & 2 & 2.2 & Others & 2 & 2.0 \\
\hline
\end{tabular}

Source: Field survey (2008)

\section{Changes in overall livelihood pattern}

In order to identify the overall socioeconomic improvement in the livelihood of household, the respondents were asked about their opinion for their overall socioeconomic change that might have taken place due to involving in garment factory. Table 12 reveals that 63.33 percent of the respondents reported that their socio-economic conditions had improved due to involving in garment factory, while 36.67 percent responded no change in their overall socioeconomic condition has taken place after involving in garment factory.

Table 12. Changes in overall livelihood pattern

\begin{tabular}{|l|c|c|}
\hline Types of changes & No. of respondents & Percent \\
\hline Improved & 57 & 63.33 \\
\hline Not improved & 33 & 36.67 \\
\hline Total & 90 & 100 \\
\hline
\end{tabular}

Source: Field survey (2008)

\section{Conclusion}

The study was conducted to assess the changing livelihood pattern of women garment workers who move from rural areas to urban garments at Dhaka city. Under the major objective the researchers tried to reveal the reasons of women for involving garment factory, work pattern of respondents in the RMG factory, monthly income by length of service and 
education category, payment schedule by age category, work hour and overtime rate, changing financial capital, decision making and empowerment and problems faced by women workers inside and outside the garment factory. Findings of the survey showed that 71.1 percent women entered the garment factory to help their family financially. It appeared that about 72 percent female workers got salary in the $1^{\text {st }}$ week of the month. Only 12.2 percent responded that their financial capital like household saving has increased after involving garment factory. The study also discovered that work at the garments was exhausting the health of the work force. Poor ventilation in the workroom is one of the dominant reasons for most of the garment worker's illnesses like headache, fainting, vomiting tendency, etc. Mental stress arising out of job insecurity can eliminated to a large extent if workers are given a formal appointment letter. Low level of education among the female workers was responsible for most of the socioeconomic problem facing the female workers in the garment industry. Hence, measures need to be adopted to encourage enrollment of girls, especially in secondary education and above, in order to improve their efficiency and reduce gender differential in wages.

Lastly, it can be said that no recommendation can be successfully implemented if all the actor, that is, the government of Bangladesh, garment employers, NGOs and above all the workers do not work together, since all the policy recommendations entail a high cost. It is true that the government of Bangladesh had very limited resources to invest in the health sector, but it could encourage the employers to invest in garment workers' health by providing tax rebate or tax holiday as incentives. The government must be diligent in implementing the labour laws. Above all the government can speed up the implementation of its policy of constructing garment villages (Garment Palli). Garment village, would solve most of the health problems the garment workers face due to uncongenial physical conditions of the workplace.

\section{References}

BGMEA (Bangladesh Garment Manufacturers and Exporters Association) Member's Directory. 2008. Annual Report. Dhaka, Bangladesh. pp. 4-7.

Halim, S. and A. H. Kabir. 2005. Globalization, Gender and Labour Market: Some Evidence from RMG sector. A Journal of Social Science. 22(1): 29-42.

Kabeer, N. 2000. The Power to Choose: Bangladeshi women and labour market decisions in London and Dhaka. Verso Press, London and New York.

Paul-Majumder, P. 2003. Health Status of the Garment Workers in Bangladesh. Agrambagh, Motijheel, Dhaka: Bangladesh at Associates Printing Press.

Sobhan, R. and . Khundker, N. 2001. Globalization and Gender. Dhaka, The University Press Limited.

World Bank. 1990. Garments: Global Subsector Study. 